\title{
Mathematical Problem-Solving Process: Negative Mental Behaviours Displayed by Pre-Service Mathematics Teachers
}

\author{
Mustafa OBAY \& Halil Coșkun ÇELIK ${ }^{2}$
}

\begin{abstract}
The aim of this study is to reveal various reasons that prevent the solution of pre-service mathematics teachers in their mathematical problem-solving process. The case study was used in the research in accordance with the qualitative research approach. Participants of the study consisted of 24 pre-service teachers who were selected by purposeful sampling method and studying mathematics education department of education faculty in a state university. Participant observation process and interview form were used to collect the data. According to the results of the study, it was determined that the pre-service mathematics teachers used monotonous approaches for the solution in the problem-solving process, they had insufficient knowledge, had anxiety and prejudices, and also displayed some mental errors.
\end{abstract}

Key Words: Reasoning, Mathematics Knowledge, Connection, Problem-Solving, Mental Errors.

\section{Matematik Öğretmen Adaylarının Problem Çözme Sürecinde Sergiledikleri Olumsuz Zihinsel Davranışlar}

\section{$\ddot{O} z$}

$\mathrm{Bu}$ araştırmanın amacı matematik öğretmen adaylarının matematik problemi çözme sürecinde çözümü engelleyen birtakım nedenleri ortaya koymaktır. Araştırmada nitel araştırma yaklaşımına uygun olarak durum çalışması kullanılmıştır. Araştırmanın katılımcıları bir devlet üniversitesinin eğitim fakültesi, matematik eğitimi anabilim dalında okuyan, amaçlı örnekleme yöntemiyle seçilen 24 öğretmen adayıdır. Verilerin toplanmasında katılımcı gözlem süreci ve görüş̧e formu kullanılmıştır. Araştırmanın sonuçlarına göre matematik öğretmen adaylarının; problem çözme sürecinde çözüm için tekdüze yaklaşımlar kullandıkları, bilgi yetersizliklerinin olduğu, kaygı ve önyargılarının bulunduğu, ayrıca bir takım zihinsel hatalar sergiledikleri belirlenmiştir.

Anabtar Kelimeler: Akıl Yürütme, Matematik Bilgisi, İlişkilendirme, Problem Çözme, Zihinsel Hatalar.

\section{Atıf İçin / Please Cite As:}

Obay, M., \& Çelik, H.C. (2021). Mathematical problem-solving process: Negative mental behaviours displayed by pre-service mathematics teachers. Manas Sosyal Arastrmalar Dergisi, 10(4), 2176-2190.

\footnotetext{
${ }^{1}$ Dr. Öğr. Üyesi - Siirt University, Education Faculty, mustafa.obay@gmail.com

ORCID: 0000-0002-2537-9438

2 Doç. Dr. - Siirt University, Faculty of Education, hcoskun.celik@gmail.com

(iD) ORCID: 0000-0003-0056-5338
} 


\section{Introduction}

In line with the added complications of the modern world, problems are similarly becoming more complicated. Having an increased accumulation of knowledge makes us expect to solve problems easier. However, knowledge on its own is not enough to solve problems, and it is widely accepted that some additional skills, such as reasoning, are also required. In particular, it is clear that if individuals are aware of their mental structure and the systematic mistakes they make in their thoughts, this will have a positive effect on their problem-solving behavior (Shaughnessy, Vennemann, \& Kennedy, 2008). Accordingly, being aware of the positive behaviour sequences and identifying negative behaviour sequences will affect an individual's free-thinking approaches and enable him to produce more creative solutions. Such an approach will also have an effect on teaching and learning mathematics. Hence problem-solving in mathematics maintains its place in general education. According to Tambychik and Meerah (2010), many mathematical skills (reasoning, reading comprehension, computational skills) are related to problemsolving. In this sense, the factors effecting problem-solving need to be taken into consideration with all their aspects during problem-solving process. But it should not be forgotten that problem solvers (preservice mathematics teachers) are educated individuals. Therefore, the behaviours displayed by individuals to solve problems when they encounter problems need to be well-analyzed and the analyzed behaviours need to be arranged.

Assessing the approaches of undergraduate students towards mathematical problems, Tall (2002) states, "for many undergraduate students, problem-solving means learning the content of a series of lecture notes and applying this knowledge to specific problems clearly related to the material being thought". Another approach considers that the effects of problem-solving strategies may be in different levels on the development of problem-solving skills (Altun, Memnun, \& Yazgan, 2007). In this sense, it has been reported that a suitable problem-solving strategy is important in succeeding in problem-solving (Ersoy, \& Güner, 2015), but selecting the right strategy does not always guarantee the right answer (Erbaş, \& Okur, 2012). Going back and re-thinking makes it possible to enhance knowledge and develop problem-solving skills (Ersoy, \& Güner, 2015).

In addition to these, cognitive and psychological factors may have an effect on thinking ability with regards to the use of mathematical problem-solving skills (Tambychik, \& Meerah, 2010). Hence, it is possible to say that problem solving behaviours are the observable products of mental activities during problem solving process (Erden, 1986). Even though the learners may have intuitively sufficient knowledge about problem-solving, they should still be thought on how to think, how to reason and how to solve problems (Posamentier, \& Krulik, 2016). This leads us to the conclusion that it is important to have knowledge about cognitive and affective factors that are believed to have an effect on problemsolving. Cognitive factors related to problem-solving are knowledge about mathematical concepts, logical thinking and power of reasoning, memory, calculation skill and estimation; while affective factors are the willingness to solve a problem, self-confidence, stress and anxiety, uncertainty, patience and ambition, being interested in problem-solving or in problematic situations, motivation, desire to succeed and the desire to satisfy the lecturer (Aydoğdu, \& Ayaz, 2008). In addition to these, the failure to concentrate on problem-solving process may cause a lack of "approval of the answer" in problem-solving (Tambychik \& Meerah, 2010). However, this could not always end in a positive manner. Seeking the approval of the lecturer may sometimes lead to dependent-thinking, which is not a desirable thing.

Tambychik and Meerah (2010) have reported that students are facing difficulties in mathematics problem-solving due to incapacity in acquiring several mathematical abilities and also lack of cognitive abilities in learning. It has been emphasized that in general, students mostly fail to completely acquire this skill, and cognitive learning skills such as remembering, memorizing and perception ability play an important role on problem-solving (Tambychik, \& Meerah, 2010). In this aspect it is known that one of the main factors affecting problem-solving process is the deficiency in the information types used. On the other hand, Thanheiser et al. (2014) concluded pre-service teachers are trying to solve mathematics problems without fully understanding the main mathematics ideas behind their strategies and they possess procedure-based information. Looking at the issue from the perspective of lecturers, lecturers cannot offer simple solutions to a problem and they need to define their cognitive and upper-cognitive processes as they solve problems (Fernandez, Hadaway, \& Wilson, 1994). They need to characterize their actions, behaviours and thoughts through mental management and such a modelling includes looking at samples 
to assess an individual's understanding about a problem, producing possible approaches, making a selection among such selections and monitoring process.

In consideration of the elements with a positive impact on problem-solving, Schoenfeld (1985), defines four different information categories that contribute to problem-solving; a) Content knowledge, b) Intuitive screening: c) Control: General decisions on the selection and implementation of resources and strategies; planning, monitoring and assessment, decision taking, conscious metacognitive behaviours d) Student's belief systems: An individual's "mathematical philosophy of life, factors defining an individual's behavior (not necessarily conscious); beliefs on individuality, environment, subject and mathematics are significant (p. 15).

On the other hand, psychology literature related to problem-solving indicates that there are evidences of schema-based actions appearing as people solve problems. Several studies on the issue are indicating that the information area structures of experts are different than those of amateurs (Chase \& Simon, 1973; Chi, Glaser \& Rees, 1982; Conveyed by: Driscoll, 2012). So, when someone makes an attempt to solve a problem, experts and amateurs create different mental models to guide their efforts. Such resulting models may not always be perfectly operational models. While helping to complete some processes with success, these schemas or strategies may fail in some other processes (Driscoll, 2012).

In this sense, expert problem solvers use a much of time to analyze the problem when solving a problem and when necessary they are more inclined to change their solution strategies (Schoenfeld, 1985). Hence experts are more flexible in problem-solving (Norqvist, 2016). Making use of concepts and skills during problem-solving process helps students to develop their mathematical thinking and reasoning (Baki, 2018).

Another factor with an impact on learning and problem-solving is the connection ability of learners. Mathematical connection is a compound of a schema or a related group of schemas in mental network (Arjudin, Sutawidjaja, Irawan, \& Sa'dijah, 2016). Forming a mathematical connection is a process that takes place in the mind of the student and such connection is the student's own mental structure existing in his mind (Businskas, 2008). Naturally, connection is closely related to discernment. Indeed, discernment is one of the focal points of mathematics education. "Reasoning (discernment) can be defined as a process of acquiring new knowledge by using tools specific to mathematics (symbols, definitions, relations, etc.) and thinking techniques (induction, deduction, comparison, generalization, etc.)" (Ministry of National Education [MoNE], 2013, p. 5). Reasoning does not have to be necessarily based on logic and therefore it is not limited to proof; it can still be wrong despite the existence of some supportive reasons (Bergqvist, \& Lithner, 2012). Umay and Kaf (2005) state that defective reasoning reveals some clues about how a student thinks, despite leading to mistaken results. Mathematical reasoning plays a central function in justifying or proving mathematical claims (Ball, \& Bass, 2003). Considering certain mathematical ideas and procedures as absolute facts or routines is insufficient when it comes to be flexible in using these ideas in different circumstances and mathematical reasoning, when required, is indispensable to re-form forgotten information (Ball, \& Bass, 2003).

It can be accepted that the factors affecting mathematical competence are negatively affected by unsuccessful experiences and inadequate strategies in problem-solving. Problem-solving skill is closely related to mathematical competence. Because problem-solving requires a person to make use of his knowledge, skill, experience and reasoning abilities and to reach a solution. In this sense, there are a number of aspects of mathematical competency. For instance, according to Lithner (2000), a significant element of mathematical competence is to be open and able continuously doubt one's position in different situations. In this context, it is important to identify the factors obstructing mathematical competency. According to Lithner (2000), even skilled students and mathematicians can make mistakes, whether big or small, however, if the mistakes are detected and corrected in within a reasonable time, then this will not be a major disruption. However, Lithner (2000) has revealed the difficulties, as well as the reasons behind the difficulties, encountered by students when performing a task or solving a problem, and he has concluded that one of the common characteristics of students is not mathematical reasoning and correctness, but rather it is to concentrate on something they are familiar with and they are able to remember. From this perspective, the definition by Umay and Kaf (2005) "the indications used by students when solving a problem will help us to understand how the think and reason, some students reduce the problem to verbal expressions, while others use spatial figures", will be important when getting 
to know the mental structures of students. However, it could not be right to assume that the mental status of students would be constantly sufficient during this process.

Preliminary beliefs of an individual occupy an important place during the problem-solving process. The effect of preliminary beliefs on learning has significant results on education. In particular, when someone is being thought about any subject, he may be unable to ignore his preliminary beliefs. Most of the time a student will try to internalize new information through his previous beliefs. The best attitude about education is to clearly eliminate such preliminary beliefs. This way, in case they are wrong, the lecturer can easily intervene to such beliefs (Atkinson et al., 2010).

Automatic behaviors; they are behaviors such as driving an automobile and riding a bicycle. Once learned, they no longer require attention (Atkinson et al., 2010). However, in the process of mathematical problem-solving, automatic behaviors rapidly turn into behaviors that have negative effects, such as assigning variables and setting up equations without thinking enough. Mental behavior is the imagination of the effects of the possible consequences of this action on the situation when an individual performed a certain behavior in the past (Atkinson et al., 2010). These mental behaviors; it is influenced by the individual's preconceptions, habits, and individual problem-solving strategies that have worked in the past. People use it as a way of discovering similarity, because similarity is often related to probability and it is easier to think that way (Atkinson et al., 2010). However, this also makes it easier for us to make mistakes. This situation, which seems positive in this respect, has a negative effect in some problem-solving situations. The teaching of mathematics refers to actions specifically intended to promote the learning of mathematics, usually in formal classroom settings. The specific actions taken depend on views of what is fundamental to mathematics itself, what prior knowledge students have, and the environment in which they can best learn mathematical habits of mind (Spielberger, 2004, p. 589)

Under the light of the above given definitions, it is believed that it is possible to gain some information about the general mental habits of pre-service teachers. Hence the purpose of this study is to analyze the mental and automatic behaviours displayed by pre-service mathematics teachers during the process of problem-solving. Under normal conditions, studies addressing problem-solving strategies are concentrating on the most commonly used problem-solving strategies and the reasons for it (Altun, Memnun, \& Yazgan, 2007; Gümüss, \& Umay, 2017; Gurat, 2018; Intaros, Inprasitha, \& Srisawadi, 2014; Sayg1l, 2017). However, the mental and automatic behaviours displayed during this process by individuals are not taken into consideration in an appropriate manner, despite the fact that such kind of behaviours is indirectly, if not directly, effecting problem-solving. The effect believed to be significant for the purposes of this research study is to concentrate on some negative behaviours (habits related to the problemsolving process, assigning variables quickly and without thinking), negatively effecting an individual solving a problem so that their repetition can be prevented. As such behaviours are directly related to the concept of self-regulation, it is clear that it will have a direct impact in the future on behaviour change in problem-solving. Therefore, the detection or diagnosis of such multi-dimensional behaviour by learnergroups and also forming an idea about their possible causes will make it easier to control the negative behaviours or the habits preventing problem-solving of the learners during the process. And with this aspect, it will have a positive effect on problem process. In this sense, the concern of the research study is to reveal the cognitive and affective obstacles that impact the problem-solving process of pre-service mathematics teachers.

\section{Method}

This research has used case study model, a type of qualitative research methods. Case study is a deep portrayal of a limited system (Merriam, 2013). Case study can also be defined with its unique characteristics. Common characteristics of case studies are certainty, portrayal and intuitivism (Merriam, 2013). Similar to other qualitative methods, these studies take place within a natural setting such as a classroom, a neighborhood, an organization etc., and target the holistic interpretation of the setting and events subjecting to the study (Yıldırım, \& Şimşek, 2004). In the present study, it was aimed to examine the difficulties that prospective teachers encounter in the mathematical problem-solving process in depth. However, as it aims to reveal why and how pre-service teachers made mistakes in the problem-solving process, it was discussed within the scope of the case study. 


\section{Participants}

Participants of the study consist of 24 pre-service mathematics teachers (16 females 8 males) studying senior grade at the Faculty of Education, Mathematics and Science Education Department of a public university. Participants of the study have been selected through purposeful sampling method on a voluntary basis (Punch, 2005). During the data analysis process, pre-service teachers have been indicated as $\mathrm{T} 1, \mathrm{~T} 2, \mathrm{~T} 3, \ldots$ due to ethical reasons.

\section{Data Collection Tools}

Data collection tools used in this study is semi-structured interviews, observations and document reviews. Semi-structured interviews took place at the end of each course, by taking written opinions of pre-service teachers. The observation results from previous courses have also been used while getting the opinions of pre-service teachers. In general, opinions were taken in writing 15 minutes before the end of the course. The prominent data collection method of this study was the participant observation method. In line with this approach, the process has been particularly analyzed in detail, reactions of the pre-service teachers have been correctly interpreted and pre-service teachers have been directly asked questions to make clarifications of unclear parts in order to get the correct meaning of the behaviour. Rather than using a structured or semi-structured form for the observation, our preference was a direct monitoring and assessment of the behaviours that took place during the course. Such observation in literature is named "what is happening in here" (Breakwell, Smith, \& Wright, 2012) and are being conducted without observing any patterns. In general, these observations include an open-ended process containing general questions posed by the researcher that allow the participants to freely state their opinions (Creswell, 2013). Document review has only been used to clarify the meaning in cases where the expressions used by the pre-service teachers being reviewed were unclear.

\section{Data Analysis}

According to Merriam (2013) a case study is an intense and holistic definition or analysis of a single and correlated structure. Data are generally acquired from interviews, on-site observations and documents. Patton (2014), with regards to case study, states "Case records get into cooperation and organize several situational data as a comprehensive and basic resource; case records include all significant information to be used in case analysis and case study. Information is arranged, surplus information is removed, parts are brought together and made available as a subject". The process in the current study has been conducted in accordance with a case analysis.

\section{Research Process}

With regards to problem process, the Middle School Mathematics Teaching Undergraduate Program Senior Grade subject "Problem-solving Strategies" has been preferred. This subject is given for a period of 14 weeks during the fall semester and has a 3-hour a week implementation. Under the scope of this subject, problem-solving strategies are given both in theory and in practice.

The research process took 12 weeks to complete. The initial two weeks of the research has been designed as a pilot study and during those two weeks problem solving-related information of pre-service teachers have been reviewed. They acquired that information during the previous courses. At the end of this initial process, it has been observed that most of the pre-service teachers are familiar with some of the strategies only as a name. Another assessment was made on their behaviours against non-routine problems. With the purpose of reaching the basic awareness and opinions of pre-service teachers on problem-solving, an outcome question has been posed on the $12^{\text {th }}$ week and a comprehensive assessment of the process has been requested from them. The main target of the researchers in this assessment was to acquire the personal assessments of pre-service teachers on why they are failing to solve problems. The most commonly posed question throughout the research process were mostly on trying to make the preservice teachers aware of their own mental habits and to get to know their mental handicaps by using that awareness. The final assessment question posed at the very end mostly targeted to reveal this condition and to understand the awareness and mental conditions of pre-service teachers.

Rather than telling pre-service teachers which method to use for each specific condition during the problem-solving process, this study has preferred to pose them non-routine problems which are suitable for the structure of the research and require some strategies. The problems in question have been assorted from International Mathematics Olympics and they are non-routine problem types. Olympic problems targeting primary school second grade have been mostly preferred for the study. The reason for preferring 
this type of problems was to make the pre-service teachers aware of their own behaviours for non-routine problems which they will be encountering in their future professional lives. An average of 3 or 4 problems have been addressed per week throughout the study. The direct solutions of the problems have not been provided. However, at the end of each course, the relevant method and a sample about such method have been provided. In addition, a sufficient amount of feedback has been provided to the pre-service teachers whenever necessary. 120 minutes of a three-hour course has been allocated to the pre-service teachers to let them solve problems. Questions have been asked from time to time to eliminate the doubts in some observations of the problem-solving processes.

\section{Findings}

In this section of the research, first the findings acquired through observation method have been given and then pre-service teachers have been posed open-ended questions to clarify the problem of this research. No problem-solving strategies have been taught to pre-service teachers at the beginning of any courses throughout the research process. However, the method used during the course has been summarized at the end of the course. No clues of any kind have been provided during the first two weeks and pre-service teachers have been observed to see the way they approach to problem-solving and what kind of reactions they give during such approaches. The pre-service teachers have been observed to be really tense during the observation process. Pre-service teachers have been observed each week under the scope of the study. Findings acquired from these observations are given below.

\section{Week I}

Observation 1: The general observation was that right after the posing of the question, pre-service teachers were immediately trying to solve the problem without entering a process of thinking. In addition, they have also been observed to instantly give up against open ended questions which did not conform to existing patterns.

Pre-service teachers have been asked what problem-solving strategies are you using? and; T5, T6, T11, T16 replied "forming an equation, equation, finding the unknown".

\section{Week II}

Observation 2: Observation of inter-class interactions revealed that when posed a question, most of the pre-service teachers are trying to identify the subject related to the problem. Pre-service teachers have used the following expressions with regards to this issue:

\section{T1: What subject are these problems related to?}

\section{T12: These problems are the subject of what topic?}

\section{T13: What topic is this subject related to?}

\section{T15: I believe we need to get problem-solving course before getting this course.}

\section{T22: Most of these problems are verbal problems but I do not know which subject they belong to}

In consideration of the above expressions, it has been observed that pre-service teachers are mostly seeking the procedures that would enable them to solve the problem directly. They have been observed to persistently ask for the solution or the outcome of the problem. One of the most common expressions was;

\section{T19: It is a waste of time to deal with these problems.}

An expression frequently repeated by pre-service teachers throughout the second week was "we are unable to think simple". Answers received to various questions posed to pre-service teachers to clarify this expression were not found to be satisfactory. Afterwards, trying to find a solution to the issue, the pages on which the pre-service teachers solved the problems, have been reviewed. The reviewed problemsolving pages most commonly had "an unnecessary use of variables". When asked about this, almost all of the pre-service teachers answered 'yes'. The following expressions have been observed during the interclass interactions of the pre-service teachers:

\section{T24: I believe we cannot think analytically.}

T1, T8: There is something wrong with this problem. Letters of the alphabet may not be enough. 


\section{Week III}

Observation 3: During the inter-class interactions regarding the pattern finding problems, the preservice teachers have been observed to be using the following expressions.

\section{TÖ16: I believe our main issue is being unable to induce.}

\section{T3: I am trying to find a formula but there is no general formula.}

Pre-service teachers have been asked what they mean by induction. Following the observations and discussions, it has been concluded that the inductive approach they are talking about is just any generalization.

With regards to this issue, pre-service teachers have been observed to be either trying to directly form an equation or seeking a singular solution to the problem.

\section{Week IV}

Observation 4: Pre-service teachers have been observed to be seeking a formula that would frequently be used as a problem-solving strategy and most of the time they indirectly asked the lecturer conducting the research to provide them with such a formula. Pre-service teachers have stated that they always feel the necessity to use a formula as a problem-solving strategy. When asked to provide a justification for this;

T8, T13, T19: "Otherwise solution of the problem will not be right".

\section{Week $V$}

Observation 5: In general, pre-service teachers said that they are approaching problems with usual methods. During the course observations and discussions, they used expressions such as;

\section{T1, T2, T9: Setting an equation, finding an unknown}

Pre-service teachers have been told they need to use different solution methods for different problems but hey have ignored this feedback.

\section{Week VI}

Observation 6: In a very short period of time (about 5 minutes) following a question, pre-service teachers immediately made a comment, they insisted that their solution is correct without making a full explanation regarding the reasons of their solution and then, most of the time, they asked for the answer.

\section{Week XI}

Observation 7: A common type of behaviour observed in many pre-service teachers was their persistent questioning of the researcher when the researcher posed a problem. Despite being regarded as bizarre at the beginning, the reason was that the pre-service teachers were almost trying to read the mind of the lecturer and this was their way of approaching the problem.

\section{Week XII}

Under the scope of the problem-solving strategies course, pre-service teachers have been posed the following comprehensive opinion question at the end of the term, to review their opinions on problemsolving.

When you are unable to solve a mathematical problem what could be your reasons in general? What kind of mental errors do you think you are committing to prevent you from solving a problem. What thinking mistakes do you think you are repeating when solving a mathematical problem?

Five basic categories have been revealed following the data analysis. In order to distinguish these categories from observations, they have been named as conclusion categories and they are given below.

1) Uniform thinking or approach: Routine approaches

T20: It is difficult to get through unless there is a systematic and multi-dimensional thinking.

T18: Problems generally include different ways of solution and connecting them becomes a total nightmare.

T19: I believe that I am unable to perform different solution strategies requiring logic. 
T11: In addition, sometimes I also got difficulties in questions requiring more thinking so it was not only field knowledge that failed me. I think the reason for this is that so far. I memorized the problem types I've learned and find a solution accordingly. When faced with different types of problems, you are just left helpless, you are tring to liken it to older styles, trying to make something out of it but it doesn't work.

T22: It is all because we are looking at the questions from the same perspective. As we are unable to interpret the questions differently and unable to turn intangible concepts into tangible ones, we are unable to solve the questions.

T12: I believe that being unable to solve a problem is related to carelessness, lack of information, being unable to go beyond certain patterns and being closed to novelties.

T5: Approaching problem questions generally with a single-solution orientation is one of the most critical mistakes I am making.

T1: One of the reasons for failing to solve a problem is that we are unable to leave classical mathematics bebind. We are trying to progress by keeping loyal to a fixed method.

T8: Failing to do research is due to failing to make any contributions to ourselves.

If pattern approaches are considered as a category, pre-service teachers are adopting a set of patterns and continue using them. Such behaviour repetitions can be addressed within a set of mental schema plane. Such schema, where awareness does not evolve in an individual, can become a handicap in some situations.

\section{2) Lack of information}

T7: The foremost reason for us to be unable to solve mathematical problems is the lack of accumulation of knowledge about that particular subject, being unable to simplify the question.

T8: I believe that the mistakes I am making are generally connected to not being in command of the subject. biases.

T10: As we do not have a strong infrastructure, as we did not previously encounter such problems, we sometimes act on

T12: When I fail to solve a mathematics problem, I generally think that the reason is my lack of field information. In recent times I have encountered this deficiency several times. Now, as much as possible, I am working on gaining more field knowledge in the field.

T18: The most significant reason for us to fail to solve a problem is that we do not know about the subject that the problem is related to. However, knowing a subject is obviously not sufficient to solve a problem. The subject needs to be enhanced by constantly solving problems.

T17: As it is a bit difficult to recognize, it will lead us to mistaken results. Another bandicap is the use of wrong rules and formulas for a problem.

This category may be considered as lack of information. Such deficiencies recognized by pre-service teachers during problem-solving process prevent them from mathematical thinking. Accordingly, lack of information is considered to be one of the main reasons for failing to solve a problem. Lack of information is also a handicap for correct and sufficient connection. In this sense, the issue of lack of information recognized by pre-service teachers during this process is an important matter for the problem-solving process.

3) Anxiety and bias

T5: When I am unable to solve a problem, usually the reason is either stress or failing to give up the first method that I concentrate.

T9: One of the other reasons could also be the psychological conditions of the time. Excitement, anxiety, fear, stress, among other emotions, may have an impact on us when trying to solve a problem.

T22: I can list them as trying to solve the question under stress, the anxiety to correctly answer the question, etc.

T21: The longer it takes for me to solve the problem, the more stress I am in and my brain stops functioning. Facing extraordinary questions bewilders me, and put together, they all prevent me from solving the problem.

T13: The most frequent mistake I make is to panic when the question seems to be difficult. 
T14: But sometimes we need to be simple. In fact, this is where the issue of bias starts. We are making the question barder than it actually is.

T15: Other than this, the fear of being unable to solve tops everything. If I look down on the question and concentrate a bit more, it actually becomes a solvable question. Then I realize that the result is not that hard. anything.

T7: Bias, for instance the thought of I cannot solve this question because it is too complicated and I did not understand

It is clear that anxiety is a significant factor preventing pre-service teachers to solve a problem. It can be said that bias is one of the factors feeding anxiety. In consideration of the expressions given by preservice teachers, they consider anxiety and the resulting bias as a mistake. The expressions of some of the pre-service teachers included "the anxiety to correctly answering the person asking the question". Furthermore, internal psychological emotions such as stress, excitement and fear are preventing some preservice teachers to solve a problem.

\section{4) Mental errors and mental habits}

T2: However, when there is an easier way, I mean the mental errors that obstruct me, trying to do it the harder way by memorizing, being unable to see what is in front of me and thinking about the useless stuff, these could be the reasons. I believe my most common mistake of thinking could be to stay in the past rather than looking for new things in a problem I encounter. I guess I am always trying to do the hardest.

T5: I just look at the question ad thing how is it possible to simplify this? Then I turn back to the old. And I really do not want to think much about it.

T1: As a mental error, I try to concentrate on the problem, first on the given numbers. When this is the case and as I do not take the given verbal section into consideration, it all starts to go off at the very beginning. And this leads us to get the result without using all the findings available to us, which is called consumption in mathematics.

T6: Trying to rapidly solve the question without actually understanding it, using a formula or an inference that is not at all related to the problem and making a generalization.

T8: One of the biggest mistakes I make when starting to solve a mathematical problem is to get on the solution right away, without thinking at all about it.

T9: And the mistake we make that prevents us from solving a problem is, we do not know where and how to start dealing with the problem and we start trying to solve without even understanding what we asked.

T11: However, we first need to understand the problem to solve the problem. I immediately start making calculations in my mind, without even understanding the problem. When this is the case, it becomes harder to solve the problem.

T12: I frequently make the mistake of trying to solve a problem without thinking about it or about the method I need to use.

T17: I make mental errors when solving a problem, such as using multiple letters to represent the unknowns and failing to think simple and exaggerating the difficulty of the question.

\section{T4: The mistake I repeat is to insist on the first solution method that comes to my mind.} doing it.

T3: I fail to bring back my previous knowledge, and once I start solving, I tend to think that it is wrong and stop

T7: And sometimes I can find a way of solution as soon as I look at the question but then I say to myself that it cannot be so easy and then I try different methods. This prevents me from solving the problem.

In consideration of above data, mental errors seem to be among the reasons for pre-service teachers to fail solving problems. These mistakes are plenty and various. However, it seems that the common factor is not the objective status of the problem but rather it is the internal psychological factors and mental handicaps of the pre-service teachers that prevent them from solving the problem. For instance, some people approach to a problem by thinking it cannot be that easy, and this completely corresponds to an internal condition.

\section{5) Simplification}

T22: The main reasons for us to fail solving mathematical problems are our lack of information about a particular issue and our failure to simplify the question. 
T8: When we fail to use problem-solving strategies in the right place, we may be faced with possible mistakes. For instance, when we are answering a long question, we need to simplify it, break into units or analyze it. Failing to use such methods can make the question even more complex. We make this mistake frequently, we appoint letters like a, b, c... to correspond each value and this makes our job harder.

T5: I have also realized that I was trying to solve it as a whole, without dividing into parts, and this made it harder to solve.

T9: So induction, deduction these are practices that I need to break the whole into smaller pieces and then find the solution. However, I think that I am unable to use different solution strategies that require logic.

T18: I believe that I can easily reach the solution by simpliffing the question and assigning fixed values.

T1: When solving a problem, I either don't use any unknowns or I use too many unknowns. In fact, both of them are making it difficult to solve a problem. When I go through values, I cannot reach a generalization. And too many unknowns make it impossible to find a way out.

T19: The most important mistake I make when solving a problem is using too many unknowns rather than reducing the number of unknowns.

T6: Another one of my thinking errors is that I make the problem more complicated when in fact I need to divide it into pieces.

One of the most frequently encountered expressions throughout this study was simplification. Even though the pre-service teachers are assigning some different meanings to this term, it is possible to say, as some of the pre-service teachers have indicated, that they are making the question more complicated by using too many variables. Furthermore, dividing into pieces was an expression used in connection with simplification of the problem and this expression has been used by conforming to the literature. However, the situation expressed by T18 is contradicting this finding. In other words, there is a single person who believes simplification is an obstacle in front of solving a problem.

\section{Discussion and Conclusion}

Nowadays, the ability of solving a problem is considered as a significant skill in mathematics teaching. It can be said that problem-solving skills can be taught. In this sense, it is important to analyze some internal process factors which have an impact on problem-solving skills. A deeper understanding on the development of problem-solving will lead to a richer problem-solving theory that can introduce practical inferences (Wes Maciejewski, 2019).

In general, internal factors of an individual are as important as external factors when it comes to learn. Understanding the difficulties faced by students regarding the mathematical skills required for solving problems is one of the ways of helping students (Tambychik, \& Meerah, 2010). There is no doubt that the psychological condition of a individual will have a negative effect on problem-solving. Cognitive and psychological factors may have an impact on using mathematical skills and thinking when solving a problem (Tambychik, \& Meerah, 2010). From this perspective, revealing the psychological obstacles of an individual is considered to be important to eliminate the factors that prevent the individual to solve a problem. Observations, interviews and documents reviews of pre-service teachers have been performed with this in mind and the following conclusions have been made.

A limited number of studies have addressed the use of alternative approaches by mathematics students when solving a problem (Tjoe, 2019). This study, in consistence with the literature, has also revealed that pre-service teachers mostly prefer uniform approaches towards problem-solving and they cannot easily give up such an approach (approach patterns). Tjoe, in particular, reports that when it comes to solve it in a different way, the idea of "looking back" is closely related to the qualities of familiarity, fluency and flexibility. This makes even more sense when taken together with the information category given in this study. It is believed that the reason for pre-service teachers to think in such a way is because they do not consider discernment but rather try to base their solution on information.

Students who are having difficulties in solving problems are also insufficient when it comes to using cognitive, upper-cognitive and self-regulation strategies in an effective way (Babakhani, 2011). It has been observed that pre-service teachers, when trying to solve a problem, are rushing into it and are not allocating much time to think about the problem (observation 1 and mental errors category). Basically, it 
has been observed that pre-service teachers observe habitual problem-solving methods, and when that does not work, they give up pretty easily. This makes one to think that pre-service teachers do not spare much time to think. However, when this is merged with the lack of information in mathematical subjects, which is another result category, it indicates that there are also other factors involved.

It has been observed that pre-service teachers are mostly trying to base the problem on a subject when trying to solve a problem (observation 2, observation 4 and knowledge category). The assessments made on this issue similarly indicate that pre-service teachers are displaying this behaviour because they are trying to justify their solution by trying to base their solution on something and this is a significant indication ("otherwise the solution will not be right", observation 5. When this is analyzed from another perspective, it can be interpreted as pre-service teachers trying to find out the procedural information leading to the solution of the problem. Because pre-service teachers make us think that they are unable to defend with discernment in case they find another possible solution. On the other hand, the issue of not being in command of the subject, as expressed throughout the insufficient information category, indicates that pre-service teachers do not pay sufficient attention to subject knowledge. This means a double-sided contradiction. On the one hand, they are not paying sufficient attention to information while on the other hand they are seeking the required information.

Another behaviour observed in pre-service teachers during the problem-solving process is that right after being given the problems, they make a comment about the problem and once they find any solution, they do not think much about its correctness and insist that it is the correct answer (observation 7). This is in support of the idea that pre-service teachers may possess a number of mental errors (mental errors category). The expressions by pre-service teachers indicate that these existing mental errors are not temporary but rather they have a permanent status at the level of problem-solving. This is in line with the "approval of the answer" conclusion reported by Tambychik and Meerah (2010).

Another noteworthy finding of this current study was that some pre-service teachers were trying to read the mind of the lecturer (observation 11 and anxiety category). Those two pre-service teachers have been observed to be more concerned about the lecturer's opinion on the answer rather than having any concerns on the objectivity of the problem's solution. This has naturally raised some doubts about the criteria observed by the pre-service teachers. The main doubt is about the subjectivity of the correct answer. Once the lecturer approves the answer of the pre-service teacher, this leads to a misguidance that the answer is absolutely correct.

One of the main issues in education, and more specifically in mathematics education, is to define the limits placed by pre-service teachers on themselves and to implement suitable approaches to remove such limits. This can also include some biases. The bias here is that assuming the answer is known and the answer must be reached. This happens despite the fact that pre-service teachers already have a certain level of knowledge and thinking capacity, therefore it is important issue. In fact, this is a habit that starts back in primary school and it has a negative effect on individuals, preventing them from thinking straight. In this study, only two pre-service teachers actually recognized this habit, and this fact can be interpreted as a lack of awareness about the issue. In this sense, if the existences of internal and external factors that impact an individual's development are taken into consideration, it could be possible to make an individual become aware of how to deal with internal dynamics. And consequently, this could help the individual to make a better use of his own potential.

The most noteworthy thing that has been revealed throughout this study relates to the expressions used by pre-service teachers during their inter-class interactions. Some of these expressions are related to mental habits. Pre-service teachers have been observed to use some phrases that are actually limiting themselves. The final assessment stage has clearly revealed this about the pre-service teachers. For instance, the expression "And sometimes I can find a way of solution as soon as I look at the question but then I say to myself that it cannot be so easy and then I try different methods. This prevents me from solving the problem." Is not related to problem-solving strategies but rather it is an obstacle created by an internal process. Insisting on unresolved problem-solving strategies can be given as a similar example. In this sense, it is possible to say that problemsolving is also related to an individual's internal processes. Hence, if an individual is aware of his own mental obstacles when solving a problem, this can be considered as the first step of getting rid of the obstacle. This is closely related to an individual's meta-cognition and self-regulation skills and this close relation can be seen in the following expression by the pre-service teachers: "despite everything I did, I couldn't change this". 
Looking at the "simplification" related findings of pre-service teachers, they did develop awareness about their own mental conditions. As seen in many expressions, pre-service teachers are themselves turning the problem into a more difficult one. This can have multiple reasons. According to the authors, the most significant factor for this is mental habits. Because pre-service teachers believe that whatever took them to the solution in the past would always work. And when this does not happen, they experience a dilemma. They have a general idea about forming an equation and achieving a solution but this requires using variables and using too many variables makes the problem more complicated than it actually is. And in some cases, an insufficient number of variables are being used and this prevents connected thinking. It is believed that this condition is related to the meta-cognitive and self-regulation skills of pre-service teachers.

As a conclusion to this study, it would be right to say that pre-service teachers are displaying a number of mental behaviours during problem-solving process and these behaviours do not bear a conscious awareness but they appear when they become part of an internal observation process. It is believed individuals may get the opportunity to eliminate some obstructive mental habits as they grow awareness. It is advisable for future researchers on problem-solving that they make an in-depth analysis of internal and spiritual conditions of individuals during mathematical problem-solving process.

\section{Ethical Statement}

In the writing process of the study titled "Mathematical Problem-Solving Process: Negative Mental Behaviours Displayed by Pre-Service Mathematics Teachers" scientific rules, ethics and quotation rules were followed; No falsification has been made on the collected data and this study has not been sent to any other academic publication environment for evaluation. Ethics committee decision: Siirt Üniversitesi Etik Kurulu, Date: 11/01/2021, No: 13.

\section{References}

Altun, M., Memnun, D. S., \& Yazgan, Y. (2007). Primary school teacher trainees' skills and opinions on solving nonroutine mathematical problems. Elementary Education Online, 6(1), 127-143.

Arjudin, Sutawidjaja, A., Irawan, E. B., \& Sa'dijah, C. (2016). Characterization of mathematical connection errors in derivative problem solving. IOSR Journal of Research \& Method in Education, 6(5), 7-12.

Atkinson, R. L, Atkinson, R. C, Smith, E. E., Bem, D. J., \& Nolan-Hoeksema, S. (2010). Introduction to Psychology (5th Edt.). Ankara: Arkadaş publisher.

Aydoğdu, M., \& Ayaz, M. F. (2008). Redounding problem-solving skill to students in mathematics. e-Journal of New World Sciences Academy, 3(4), 588-596.

Baki, A. (2018). Knowledge of teaching math. Ankara: Pegem Academy Publishing.

Ball, D. L., \& Bass, H. (2003). Making mathematics reasonable in school. In J. Kilpatrick, W. G. Martin, \& D. Schifter (Eds.), A research companion to principles and standards for school mathematics (pp. 27-44). Reston, VA: National Council of Teachers of Mathematics.

Babakhani, N. (2011). The effect of teaching the cognitive and meta-cognitive strategies (self-instruction procedure) on verbal math problem-solving performance of primary school students with verbal problem- solving difficulties. Procedia Social and Behavioral Sciences, 15, 563-570. Doi: 10.1016/j.sbspro.2011.03.142

Bergqvist, T., \& Lithner, J. (2012). Mathematical reasoning in teachers' presentations. Journal of Mathematical Behavior, 31, 252-269. Doi: 10.1016/j.jmathb.2011.12.002.

Biber, B. T., Aylar, E., Ay, Z.S., \& İspir, O. A. (2017). Pre-service primary school mathematics teachers' pedagogical content knowledge of problem solving through interviews and in-course practice observations. Kastamonu Education Journal, 25(4), 1483-1498.

Breakwell, G.M., Smith, J. A. \& Wright, D. B. (2012). Research methods in psychology (4th ed.). Los Angeles: Sage Publications.

Businskas, A. M. (2008). Conversations about connections: How secondary mathematics teachers conceptualize and contend with mathematical connections (Unpublished doctorate dissertation). Simon Fraser University, Canada.

Creswell, J. W. (2013). Research design (S. B. Demir, Trans.). Ankara: Educating Book.

Dede, Y. (2004). Identifying students' solution strategies in writing algebraic word problems as equations. Educational Science and Practice, 3(6), 175-192.

Driscoll, M. P. (2012). Learning psychology. (Ö. F. Tutkun, S. Okay \& E. Şahin, Trans.). Ankara: Anı Publishing.

Engel, A. (1998). Problem-solving strategies. New York: Springer-Verlag

Erbaş, A. K., \& Okur, S. (2012). Researching students' strategies, episodes, and metacognitions in mathematical problem solving. Qual Quant, 46, 89-102. Doi: 10.1007/s11135-010-9329-5.

Erden, M. (1986). Behaviors of students attending the first phase of primary schools while solving four operational problems. Hacettepe University Journal of Education, 1(1), 105-113. 
Ersoy, E., \& Güner, P. (2014). Mathematics teaching and mathematical thinking. Journal of Research in Education and Teaching, 3(2), 102-112.

Ersoy, E., \& Güner, P. (2015). The place of problem solving and mathematical thinking in the mathematical teaching. The Online Journal of New Horizons in Education, 5(1), 120-130.

Fernandez, M.L., Hadaway, N., \& Wilson, J. W. (1994). Problem solving: Managing it. The Mathematics Teacher, 87(3), 195-199.

Gurat, M. G. (2018). Mathematical problem-solving strategies among student teachers. Journal on Efficiency and Responsibility in Education and Science, 11(3), 53-64. Doi: 10.7160/ eriesj.2018.110302.

Gümüş, F. Ö., \& Umay, A. (2017). Effect of problem-solving strategies instruction on preservice elementary mathematics teachers' conceptual / procedural solution preferences and problem-solving performance. Elementary Education Online, 16(2), 746-764. Doi: 10.17051/ilkonline.2017.304731.

Gümüş, F. Ö. (2015). Analysing preservice elementary mathematics teachers' problem-solving strategies preferences and mathematics self-efficacies. Electronic Journal of Social Sciences, 14(52), 34-42.

Intaros, P., Inprasitha, M., \& Srisawadi, N. (2014). Students' problem-solving strategies in problem solvingmathematics classroom. Procedia - Social and Behavioral Sciences, 116, 4119 - 4123. Doi: 10.1016/j.sbspro.2014.01.901.

Lithner, J. (2000). Mathematical reasoning and familiar procedures. International Journal of Mathematical Education in Science and Technology, 31(1), 83-95. Doi: 10.1080/002073900287417.

Merriam, S. B. (2013). Qualitative research (Trans: S. Turan). Ankara: Nobel Academic Publishing.

Ministry of National Education (MoNE) (2013). Secondary school mathematics lesson (5th, 6th, 7th and 8th grades) curriculum. Ankara: Board of Education and Discipline.

Norqvist, M. (2016). On mathematical reasoning-being told or finding out. Print \& Media, Umeå University Umeå, Sverige. Rerieved January 02, 2020 from https://umu.diva-portal.org/smash/get/diva2:954413/FULLTEXT01.pdf

Patton, M.Q. (2014). Qualitative research \& Evaluation methods (M. Bütün \& S. B. Demir, Trans.). Ankara: Pegem Academy Publishing.

Posamentier, A. S., \& Krulik, S. (2016). Problem solving in mathematics (Trans: L. Akgün, T. Kar, M. F. Öçal). Ankara: Pegem Academy.

Punch, K. F. (2005). Introduction to social research (Trans: D. Bayrak, H. B. Aslan, Z. Akyüz,). Ankara: Political Bookstore.

Sayg1l, S. (2017). Examining the problem-solving skills and the strategies used by high school students in solving non-routine problems. E-International Journal of Educational Research, 8(2), 91-114.

Schoenfeld, A. H. (1985). Mathematical problem solving. New York: Academic Press.

Shaughnessy, M. F., Veenman, M. V. J., \& Kennedy, C. K. (2008). Meta-cognition: A recent review of research, theory, and perspectives. New York: Nova Science Publishers.

Spielberger, C. D. (Ed.). (2004). Encyclopedia of applied psychology, Vol. 3 (Per-Y, index). Elsevier Academic Press

Tall, D. (2002). Advanced mathematical thinking. New York: Kluwer Academic Publishers.

Tambychik, T., \& Meerah, T. S. M. (2010). Students' difficulties in mathematics problem-solving: What do they say? Procedia Social and Behavioral Sciences, 8, 142-151. Doi: 10.1016/j.sbspro.2010.12.020

Thanheiser, E., Browning, C., Edson, A. J., Lo, J. J., Whitacre, I., Olanoff, D., \& Morton, C. (2014). Pre-service elementary mathematics teacher content knowledge: What do we know, what do we not know, and where do we go? The Mathematics Enthusiast, 11, 433-448.

Tjoe, H. (2019). "Looking Back" to solve differently: Familiarity, fluency, and flexibility. In P. Liljedahl \& M. Santos-Trigo, (Eds.), Mathematical problem-solving current themes, trends, and research (pp. 3-20). Cham, Switzerland: Springer International Publishing.

Umay, A., \& Kaf, Y. (2005). A study on flawed reasoning in Mathematics. Hacettepe University Journal of Education, 28, 188-195.

Wes Maciejewski (2019). Future-oriented thinking and activity in mathematical problem solving. In P. Liljedahl, M. SantosTrigo (Eds.). Mathematical problem solving: Current themes, trends and research (pp.21-38), Switzerland: Springer International Publishing.

Yıldırım, A., \& Şimşek. (2004). Qualitative research methods in the social sciences. Ankara: Seçkin Publishing.

\section{TÜRKÇE GENİ̧̧ ÖZET}

Günümüzün dünyasında yaşamın karmaşılklaşmasına paralel olarak problemler de benzer şekilde karmaşıklaşmaktadır. Bilgi birikiminin artış göstermesi problemleri çözmemizi kolaylaştırması beklenir. Ancak problem çözümünde bilgi tek başına yeterli gelmemekte özellikle muhakeme gibi birtakım becerilere de ihtiyaç olduğu kabul edilmektedir. Bununla birlikte gelişmiş toplumlarda bireylerin sahip olması gereken nitelikler salt bunlarla sınırlı değildir. Özellikle bireylerin kendi zihinsel yapıları hakkında bilgi sahibi olmaları, kendi düşünmelerinde yaptıkları sistematik hataları tanımaları onların problem çözme davranışını olumlu yönde etkileyeceği açıktır. Burada olumlu davranış dizgelerinin bilinmesi, olumsuz davranış dizgelerinin teşhisi bireyin daha serbest düşünme yaklaşımlarını etkileyecek ve daha yaratıcı 
çözümler üretmesini sağlayabilecektir. Bu açıdan ele alındığında matematik öğrenme ve öğretimi de bu yaklaşımdan etkilenecektir.

Bilişsel ve psikolojik faktörler matematik becerilerini kullanma ve problem çözmede düşünme yeteneğini etkileyebilir (Tambychik ve Meerah, 2010). Bu açıdan problem çözme davranışları, problem çözme sürecindeki zihinsel faaliyetlerin gözlenebilir ürünü olduğu söylenebilir (Erden, 1986). Öğrenenler problem çözme konusunda sezgisel olarak yeterli bilgi sahibi olabilmelerine rağmen, onlara nasıl düşünecekleri, nasıl akıl yürütecekleri ve problem çözecekleri konusunda öğretimler verilmelidir (Posamentier ve Krulik, 2016). Bu kapsamda öğrenenlerde problem çözme üzerinde etkili olduğu düşünülen bilişsel ve duyuşsal faktörler hakkında bilgi sahibi olmanın önemi ortaya çıkmaktadır.

Öğretmen adaylarının genel zihinsel alışkanlıkları hakkında bazı bilgilere ulaşmanın olası olduğu düşünülmektedir. Bu yönüyle araştırmanın amacı ilköğretim matematik öğretmen adaylarının problem çözme sürecinde göstermiş oldukları zihinsel ve ruhsal davranışları incelemektir. Bu araştırma açısından önemli olduğu düşünülen etkiler; bireyin problem çözmesini olumsuz etkileyen bazı negatif davranışlara odaklanarak tekrarlamasını önlemektir.

Bu çalışmada nitel araştırma yöntemlerinden durum çalışması kullanılmıştır. Araştırmanın katılımcıları bir devlet üniversitesinin eğitim fakültesi, matematik eğitimi anabilim dalında eğitime devam eden 4.sınıf okuyan 24 ögretmen adayından (16 kadın 8 erkek) oluşmaktadır. Araştırmaya dahil edilen katılımcılar gönüllülük temelli amaçlı örnekleme yöntemiyle seçilmiştir. Bu araştırmada kullanılan veri toplama araçları yarı yapılandırılmış görüşmeler, gözlem ve belge incelemedir. Yarı yapılandırılmış görüşmeler her ders sonunda öğretmen adaylarının görüşlerine yazılı bir biçimde başvurularak gerçekleştirilmiştir. Öğretmen adaylarının görüş̧erinin alınmasında önceki derslerde elde edilen gözlem sonuçlarından yararlanılmıştır. Çalsşmada gerçekleştirilen süreç bir durum analizine uygun yürütülmüştür. Veri toplama süreci 12 hafta devam etmiş ve bunun için problem çözme stratejileri dersi tercih edilmiştir.

Araştırma sürecinde her hafta işlenen derslerde ders başlangıcında öğretmen adaylarına herhangi bir problem çözme stratejisi öğretilmemiştir. Ancak ders sonunda ders sürecinde hangi yöntemin kullanılmış olduğu özetlenmiştir. İlk iki hafta herhangi bir ipucu verilmeksizin onların kendiliğinden problem çözümlerine nasıl yaklaştıkları ve bu yaklaşımlar esnasında ne tür tepkiler verdikleri gözlem yoluyla tespit edilmeye çalışılmıştır. Araştırma kapsamında öğretmen adayları, her hafta gözlemlenmiştir. Bu çalışma boyunca en sık rastlanan ifadelerden biri basite indirgeme olmuştur. Öğretmen adaylarının bu kavrama yönelik bazı farklı anlamlar yükledikleri görülse de esas olarak bazı öğretmen adaylarının ifade ettiği gibi çok fazla değişken kullanma yoluyla soruyu karmaşık hale getirdiklerini söylemek mümkündür. Bunun yanında parçalara ayırmak da problemin basite indirgemesine ilişkin bir ifade olarak kullanıldığı görülmüş bu ifade literatüre uygun olarak kullanılmıştır. Ancak bunların dışında Ö18'in ifade ettiği durum bu bulguyla çelişmektedir. Yani, basite indirgemenin problem çözmenin önünde engel olduğu görüşü de tekil olarak mevcuttur.

Genel olarak eğitimde ve özelde matematik eğitiminde temel sorunlardan biri öğretmen adaylarının kendilerine koydukları sınırlamaları belirlemek ve bu sınırlamaları ortadan kaldıracak yaklaşımları ortaya koymaktır. Bu durum çeşitli ön yargıları da barındırabilir. Burada görülmekte olan durum doğru cevabın bilindiği ve ona ulaşılması gerektiği ön yargısıdır. Öğretmen adaylarının belli bir bilgi ve düşünme kapasitesine sahip olmalarına rağmen yaşandığı düşünülecek olursa bunun çok önemli bir durum olduğu görülebilir. Esasında bu alışkanlık ilköğretimden başlayarak sahip olunan bir özelliktir ve bireylerin sağlıklı düşünmesini olumsuz etkilemektedir. Ancak bu çalışmada bu alışkanlığın farkına varma iki öğretmen adayı ile sınırlı kalması yeterli bir farkındalığın oluşmadığına yönelik yorumlanabilir. Bu açıdan bireyin belli bir alanda gelişimini etkileyen iç ve dış faktörlerin varllğ1 göz önünde bulundurulursa, bireyin kendi iç dinamiklerini engelleme farkındalıkları artırlabilir. Bu da onları kendi potansiyellerini daha iyi kullanma olanağ1 yaratacağ1 kabul edilebilir.

$\mathrm{Bu}$ çalışma boyunca karşılaşılan en dikkat çeken durumun öğretmen adaylarının sınıfı içi etkileşimlerinde kullandıkları bazı ifadelerin zihinsel alışkanlıklara yönelik olan kısmıdır. Öğretmen adaylarının kendi kendilerini engelleyen söylemler kullandıkları gözlenmiştir. Öğretmen adaylarının sonuç olarak değerlendirmelerinde bu konu özellikle net olarak ortaya çıkmıştır. Örneğin "Bazen de soruya bakar bakmaz bir çözüm bulabiliyorum ama bu kadar basit olmaz düşüncesiyle farklı yollara başvuruyorum. $\mathrm{Bu}$ durum da problemi çözmeme engel oluyor." İfadesi problem çözme stratejileri ile ilgili olmasından çok içsel bir sürecin oluşturduğu engellerdir. Benzer şekilde sonuçsuz kalan problem çözme stratejilerinde ssrar 
etmek de aynı şekilde değerlendirilebilir. Bu yönüyle problem çözmenin bireyin içsel süreçleri ile de ilgili olduğu söylenebilir. Bu yönüyle problem çözen bireyin kendi zihinsel engellerinin farkında oluşu ondan kurtulmanın ilk aşaması olarak değerlendirilebilir. Bu durumun bireyin üst biliş ve öz düzenleme becerileri ile yakın ilişkili olduğu öğretmen adaylarının "bundan bir türlü kurtulamadım” şeklindeki ifadelerinde gizli olduğu görülebilir.

$\mathrm{Bu}$ araştırmada öğretmen adaylarının problem çözme sürecinde bir takım zihinsel davranışlar gösterdikleri ve bu davranışların bilinçli bir farkındalık taşımadığı ancak bir iç gözlem sürecine dahil oldukları taktirde bu durumun ortaya çıktı̆̆1 söylenebilir. Bireylerin bu yönlü farkındalıkları arttıkça kendilerini engelleyen bazı zihinsel alışkanlıklardan kurtulabilme şansı yakalayabilecekleri düşünülmektedir. Problem çözme konusunda çalışma yapacak araştırmacılara, Matematiksel problem çözme sürecinde bireylerin içsel olarak yaşadıkları ruhsal durumların daha detaylı olarak incelemeleri önerilmektedir. 